\title{
Enhancing social support for migrant families: A case study of community services in a Shanghai urban village and implications for intervention
}

\begin{abstract}
Recent years have witnessed the growing emphasis of the Chinese central government on developing community services as a way to reconstruct communities and strengthen social solidarity. With the increased involvement of multi-generation households in China's internal rural-to-urban migration, however, little is known about what community services are available for migrant families. Nor do we know much about how such services can enhance social support for migrants, which is crucial for their psychological well-being in managing the ongoing challenges that arise from migration and further integrating into the cities.

This article presents a case study conducted in Shanghai where social services are emerging in a few urban villages. We begin with a brief background on China's rural-to-urban migration and the emergence of urban villages, followed by a discussion of community services and social support for Chinese migrant families. We then document existing services in an urban village to explore how they can influence migrant families' social support. Drawing on the perspective of service providers, we highlight the effects social work intervention can have on improving social support for migrant families. Last, we propose an intervention framework based on multi-dimensional social support, emphasizing differentiations and an integration of formal and informal social support through community services for migrant populations.
\end{abstract}

Key words: social support, migrant families, community services, social work, social policy 
Wen, Ya, \& Hanley, Jill. (2016). Enhancing Social Support for Migrant Families: A Case Study of Community Services in a Shanghai Urban Village and Implications for Intervention. Asian Social Work and Policy Review, 10(1), 76-89.

\section{Introduction}

Social support has been proven to have an important impact on migrants' psychological wellbeing and socio-cultural adaptation processes (Ryan et al., 2008; Cauce et al., 1994; Hebert et al., 2004; Harker, 2001). It has become increasingly important also been recognized as a key concept for developing community services for migrant populations (Lopez \& Salaz, 2006; Greef \& Holtzkamp, 2007; Simich et al., 2005), which raises the question of how such services can meet the social support needs of China's rapidly growing population of rural-to-urban migrants. The literature on China's internal migration indicates that, with changing patterns of migration (e.g., migration of entire households versus migration of only individuals, the extension of stays in cities, and the desire of the younger migrant generation to remain permanently in cities as urban residents), there is a growing need to promote social integration through community social services for rural-to-urban migrants (Guan, 2010; Xu, et al., 2011). However, as we have discussed in a previous article (Wen \& Hanley, 2015), many migrant families tend to rely on inadequate informal support networks, receiving little support from formal organizations and professionals, a situation echoes other studies on low participation of rural-to-urban migrants in urban welfare programs ().

Community services have been experiencing rapid expansion in urban China, in order to supplement the safety net of the state's overall welfare infrastructure. Within this context, social workers have been advocating for social services to be provided to migrant populations in migrant enclaves, the so-called 'urban villages'. Nevertheless, there are limited studies on the community services available in urban villages and little is known how these services meet the needs of migrant families for social support. To addresses this gap and to provide research evidence to guide social work practices for migrant populations in China, we conducted a case study in an urban village in Shanghai, 
Wen, Ya, \& Hanley, Jill. (2016). Enhancing Social Support for Migrant Families: A Case Study of Community Services in a Shanghai Urban Village and Implications for Intervention. Asian Social Work and Policy Review, 10(1), 76-89.

documenting community services in urban villages that are available for migrants and how these services influence migrant families' social support. Data was collected through interviews, participatory observation, and documentary analysis. From our findings, we draw implications for professionals developing community-level social work interventions for the internal migrant population in China.

\section{China's rural-to-urban migration and the emergence of urban villages}

Since the economic reforms of the 1980s, China has been going through unprecedented urbanization, and rural-to-urban migration lies at the core of this process. In the past thirty years, the country's urban population has grown by about 440 million and half of this growth is attributable to rural-to-urban migration (Cai \& Wang, 2007). According to the most recent national report, the number of rural-to-urban migrant population has increased to 245 million in 2013, accounting for more than one-sixth of the country's total population (National Health and Family Planning Commission, 2014).Although migrants from rural areas move to cities in search of a better life, they often find themselves caught up in rural-urban divisions and the limitations of the hukou registration systeman institutional instrument to control population mobility. Many can only take low-wage, long-hour physical work that is unappealing to local residents. Without access to urban housing subsidies, they have to live in impoverished urban areas or on the city fringes, called 'urban villages'. The term literally means 'villages in the city' (chengzhongcun in Chinese), denoting the villages that have been surrounded or otherwise encroached upon by urban expansion, when farmlands or villages on the city fringes are acquired by municipal governments. Eventually, indigenous farmers give up farming practices to construct inexpensive housing units that they can rent to city newcomers (Song, Zenou, \& Ding, 2008). An urban village is not an officially defined administrative unit, but rather a migrant 
Wen, Ya, \& Hanley, Jill. (2016). Enhancing Social Support for Migrant Families: A Case Study of Community Services in a Shanghai Urban Village and Implications for Intervention. Asian Social Work and Policy Review, 10(1), 76-89.

enclave that transcends geographical, social, administrative, and ideological boundaries of the established system (Ke \& Li, 2001). Characterized by high residential mobility, substandard housing construction and poor community infrastructure, urban villages have been a concern of city managers because of the perceived risks they present to public health and security and are discouraged in governmental discourse (Sun, 2013). As the number of rural-to-urban migrants - and their demands for affordable accommodations - continues to rise, there is a growth of urban villages, especially on the outskirts of large cities like Beijing and Shanghai. While official statistics are difficult to obtain, according to Sun (2013), there were 189 urban villages in Beijing and 104 in Shanghai in 2013.

\section{Theoretical considerations of the study}

Theoretically, social support is a multidimensional construct that encompasses physical and instrumental assistance, attitude transmission, resource and information sharing, and emotional and psychological support (Lopez \& Salas, 2006). Social support can be divided into various categories according to the functional and structural aspects of the concept. In terms of functional aspects, four types of social support are identified and commonly used in research (Heaney \& Israel, 2008). Emotional support is defined as expressions of empathy, love, trust, and care. Instrumental/material support encompasses the concrete and direct ways people assist others, including financial assistance, material goods, or services. Informational support is defined as advice, suggestions, and provision of general information. And companion support refers to social companionship consisting of activities providing affiliation and contact with others, bringing people a sense of belonging (Heaney \& Israel, 2008). Diverse sources of social support are important, for people may provide various forms of support in varied ways and at different times, but it is not likely that one single network can provide all four forms of support (Wellman \& Hiscott, 1985). 
Social support can be provided through both informal and formal channels. Informal support is identified as closely related to an individual's social network, such as friends, family members, and colleagues, while formal support is provided by official systems, including social services, organization, schools and institutions, and professionals (Caplan, 1974). The literature suggests that informal social support is of particular relevance for migrants, helping them to meet their immediate settlement needs, providing social participation opportunities and contributing to an enhanced mental health (Heaney \& Israel, 2008). However, the interpersonal aid available through social networks is often not enough, given the complex needs of migrant families integrating to the host societies (Wen \& Hanley, 2015; Neufeld, et al., 2002). Social programs and services are necessary to promote equal opportunities and a fair distribution of resources, especially for socially disadvantaged groups like migrants (Simich, et al., 2005).

\section{Policy framework for community services in China and social support for rural-to- urban migrant families}

Since the 1990s, with the decline of the danwei system, in which employment-related work units provided for urban residents' overall welfare services, policy makers have aimed to transform community-level administrative bodies into service delivery mechanisms. Community services were thus considered to be an alternative way of providing a supplemental safety net in urban areas, while the central government continued to supply the overall welfare infrastructure which included subsidized housing and medical benefits (Xu \& Chow, 2006). In 1994, the Ministry of Civil Affairs (MCA), along with 14 other government ministries, proposed an official scheme to promote community services: "under government guidance, street-level organizations and the lower level of neighbourhood committees, are to address the various needs of the community by providing welfare services to residents" (MCA, 1995). Community Neighbourhood Committees (CNCs) were then 
Wen, Ya, \& Hanley, Jill. (2016). Enhancing Social Support for Migrant Families: A Case Study of Community Services in a Shanghai Urban Village and Implications for Intervention. Asian Social Work and Policy Review, 10(1), 76-89.

designated as para-governmental grassroots administrative and service delivery organizations at the bottom of the urban administrative hierarchy (Yan \& Gao, 2007). The majority of community services targeted the general welfare population with a wide range of issues, including employment, housing, health care, elder care, crime prevention and education. CNCs also provided residents with recreational activities, educational programs, and fee-charging services such as convenience stores (MCA, 1995).

A typical model of service provision and urban administration would be "Two levels of government, three levels of management, and four levels of services". Among the four levels of services - city, district, street office, and $\mathrm{CNC}$ - the street office, which represents at least 5,000 households and regulates local workshops, schools, nurseries, health clinics, stores, and community centres, is mainly responsible for service provision, although the $\mathrm{CNC}$ assists with the implementation (Xu \& Chow, 2006). However, as transitional communities, urban villages do not fit within the scope of the traditional urban administration and social service provision, which is based on the number of residents whose hukou is registered in local jurisdiction (Gransow, 2011).

The content of community services has been gradually developed and modified. Table 1 presents a chronology of government documents related to community services.

\section{Table 1}

\begin{tabular}{|l|l|}
\hline \multicolumn{1}{|c|}{ Policies and regulations } & Year \\
\hline $\begin{array}{l}\text { "Urban Community Neighbourhood Committee (CNC) Organization Act", CNC was designated as para-governmental } \\
\text { grassroots organization to implement administrative duties and service provision at the level of communities. }\end{array}$ & 1989 \\
\hline $\begin{array}{l}\text { MCA's "Opinions on accelerating the development of sectors of community services", first proposing the official } \\
\text { definition of community services in China. }\end{array}$ & 1995 \\
\hline $\begin{array}{l}\text { MCA's "Opinions on promoting urban community development throughout the country", emphasizing community } \\
\text { services as an important part of developing urban communities and the responsibilities of all levels government in } \\
\text { developing community services. }\end{array}$ & 2000 \\
\hline $\begin{array}{l}\text { MCA's "suggestion on strengthening and improving community services", redefining community service and } \\
\text { emphasizing providing public services in developing community services. }\end{array}$ & 2005 \\
\hline
\end{tabular}


Wen, Ya, \& Hanley, Jill. (2016). Enhancing Social Support for Migrant Families: A Case Study of Community Services in a Shanghai Urban Village and Implications for Intervention. Asian Social Work and Policy Review, 10(1), 76-89.

\begin{tabular}{|l|l|}
\hline $\begin{array}{l}\text { State Council's “Opinion on strengthening and improving community services”, emphasizing central government's } \\
\text { direction and supervision on developing community services. }\end{array}$ & 2006 \\
\hline $\begin{array}{l}\text { State Council's "Five-year plan on establishing community service system”, establishing community service system } \\
\text { as important part of innovative governance. }\end{array}$ & 2011 \\
\hline $\begin{array}{l}\text { The party's 18th report, including strengthening services provision in rural and urban communities as an imporatn part } \\
\text { of governance to promote social solidarity. }\end{array}$ & 2012 \\
\hline
\end{tabular}

Before 2006, substantial changes in policy have been made to frame formal support for rural-tourban migrants, mainly focusing on education of migrant children and labour rights of migrant workers. Education is a social entitlement attached to hukou registration, so children of rural-to-urban migrants used to be denied entry to the public education system in cities. Since 1996, the central government started to tackle the problem by making a series changes on policies, including the 1998 "provisional measure for the schooling of migrant children and young people" and the 2003 State Council's "Opinon on further improving the work of compulsory education for the children of migrant workers in cities". In addition, the 'Urban Five', a national insurance program, was established in 2000 to include migrant workers in urban welfare systems, which consists of five work-related public insurance programs to improve migrant welfare: (1) basic healthcare, (2) old age pensions, (3) unemployment insurance, (4) workers compensation, and (5) maternity benefits for working mothers (Xu, et al., 2011). Moreover, national programs were implemented to facilitate rural-to-urban migrants working in cities, such as "The training plan for rural migrant workers in 2003-2010" and the Sunshine project that was initiated in 2004 aiming to provide occupational training in rural areas to help people find jobs in cities. However, most of these benefits for migrants were attached to employment experience; access to community services for rural-to-urban migrants was therefore limited.

In 2006, the State Council released its "Opinion on Resolving the Problems Faced by Migrant Workers", which introduced a comprehensive scheme of state support for rural-to-urban migrants. Besides confirming that urban local governments were responsible for providing migrant children's 
compulsory education, the Opinion also proposed to resolve many of the problems faced by rural migrant workers, including low wages and wage arrears, bringing the labour management of rural migrants into line with legal regulations, job-seeking services, occupational training, social security, urban public services, and improving safeguard mechanisms that protect rural migrants' rights and interests (The State Council, 2006). In emphasizing migrants' entitlement to urban public services, the Opinion represents a major shift toward social inclusion and integration for rural-to-urban migrant workers and their families.

In addition, the State Council released the "Opinion on strengthening and improving community services" in 2006, regulating the central government's investment and supervision with an emphasis on increasing public services in developing community services. The Opinion specifically emphasized the government's investment in subcontracting social services from social organizations, which provided social work professionals with a basis to expand the scope of their services for the migrant population and spurred many service programs in urban villages (Leung, 2013). Moreover, in the 2011 "Five-year plan on establishing a community service system", building community service system was proposed as a way to strengthen governance and social solidarity ().

Among the handful of studies on these programs, Gao (2011) described social work practices in an urban village in Yunnan province, providing educational programs for migrant children, household visits, services in maternal and reproductive health, legal aid, counselling in labour rights, etc. It was suggested that community services would be more effective with a focus on migrants' strengths, helping them to improve their abilities and awareness to solve problems and improve social justice (Gao, 2011). In another study, He (2011) described social services in an urban village in Guizhou, which focused on providing services for migrant children as an extension of social work services in 
migrant children's schools. Wen (2013) presented a trial program in which social workers conducted comprehensive social services in an urban village in Shanghai through a 3-year project funded by local street-level government. The project was also expected to provide lessons for the local government in collaborating with social work professionals and improving governance with migrant population (Wen, 2013). Yet, there remains a lack of in-depth understanding of community services for the migrant population, and social work practices in urban villages would be strengthened by research findings related to the enhancement of social support for migrant families.

\section{Methodology: Documenting social services in an urban village through a case study}

We used a case study ${ }^{1}$ to examine the social services available in a Shanghai urban village for migrant families and we asked how these services affect social support for migrant families. T village is a typical urban village, which was chosen as the research site due to its existing connections to a research network. Located beside the southwest outer loop of Shanghai, more than $90 \%$ of its residents are rural-to-urban migrants. The 2010 census showed that there were more than 2,000 registered households in $\mathrm{T}$ village and that it had a total population of around 7,000. Migrants living in T village are mainly employed as factory workers, construction workers, cleaners, domestic helpers, small business vendors, drivers, garbage recyclers, and salespeople.

The data was collected from March to June 2013 and again in July 2014 when the principal researcher conducted fieldwork in $\mathrm{T}$ village. The methods involved in data collection included documentation (e.g., policy documents and written materials related to service provision found in the village); interviews, including key informant interviews with social workers, service providers, community workers, local government officials $(\mathrm{n}=11)$ and a focus group interview with social work

\footnotetext{
${ }^{1}$ Part of a larger study investigating social support for Chinese rural-to-urban migrant families and migrant children
} 
Wen, Ya, \& Hanley, Jill. (2016). Enhancing Social Support for Migrant Families: A Case Study of Community Services in a Shanghai Urban Village and Implications for Intervention. Asian Social Work and Policy Review, 10(1), 76-89.

interns who were involved in service delivery in T village $(n=5)$; and the principal researcher's own observations. The participants for the interviews were asked to describe their work related to service provision in T village and how such work helped enhancing social support for migrant families.

\section{Findings: Emerging social services in T village}

In this section, we describe the context in which social services have been developed in T village, followed by a categorization of the different types of influence that community services can have on migrant families' access to social support.

\subsection{The context for the development of social services in $T$ village}

Social services for migrants were initiated by social work professionals, who saw the growing needs of community services for migrants in $\mathrm{T}$ village. A neighbourhood committee was assigned in $\mathrm{T}$ village in 2002 as a result of the indigenous farmer in T village moved to more central parts of the city after their farmlands were annexed by city government, and they rented their houses to the many newcomers who were attracted to Shanghai by employment prospects without being able to afford typical urban accommodation. However, with a mandate so tightly linked to hukou registration, the neighbourhood committee was incapable of providing services to unregistered migrants. A member of the neighbourhood committee recalled the difficulty of working with these migrants:

One of our daily duties is family planning... It was very difficult dealing with migrants, for they tried to hide from us, and we didn't get credit for doing it. So we leave most of the work (providing services to migrants) to social workers. (c8)

Shanghai was one of the first cities to introduce social work education and practices, and it had the most developed social work profession. In addition, the Shanghai municipal government pioneered a project-purchasing (subcontracting) scheme for social work projects, which set up a basis for social work practices in T village. In this project-purchasing scheme, non-governmental social work service organizations could bid for service contracts (funded mainly by the government) through an open- 
tendering process. Accordingly, the majority of social services provided in T village by social workers came to be funded by the Shanghai Civil Affairs Bureau (SHCAB) through a community bidding process. Still, local resources and the support from the neighbourhood committee have been important to social workers, especially in the beginning of their conducting social services in $\mathrm{T}$ village. One social worker described the difficulties of that initial service program in $\mathrm{T}$ village:

At the beginning, no one in T village knew what social workers were and what we do. Migrants did not trust us neither, thinking government sent us. We had to be patient to have them understand our work here was to help them. We arranged household visits, sending our many brochures about our work, and organized free outdoor movies and other activities. Eventually migrants in the village got familiar with us and are willing to share with us their concerns. (A2)

At the time of the study, service provision for migrants in $\mathrm{T}$ village consisted of three parts: services provided by social workers, which consist of project-based programs that are mainly funded by SHCAB or external resources; regular services conducted by the neighbourhood committee according to their administrative duties, such as family planning and environmental protection; and the work done by the Migrant Administration Office (MAO), the representative of local police offices in migrant communities whose work duty is migrant registration and crime prevention. ${ }^{2}$ The neighbourhood committee represents the government at the community level and oversees the general administrative duties in $\mathrm{T}$ village. They collaborate with social workers in providing services to migrants and the MAO provides assistance to the neighbourhood committee for community security management.

\subsection{Community services as formal social support for migrant families}

To date, more than 45 service programs are available to migrants in $\mathrm{T}$ village and mainly provided

\footnotetext{
2 The MAO is affiliated to the Ministry of Security. Their main responsibility is to strengthen the administration of floating population and reduce crime among migrants in communities where the migrant population is concentrated. Although there is little evidence, urban villages are associated in the public mind with a risk of crime, and the presence of unregistered migrants is seen as a danger to public security. The MAO is therefore mandated to register migrants in order to increase security and facilitate investigations should crimes occur.
} 
by the social workers (see Table 2 for an overview). These services aim to address migrant families' needs for social services, including youth services, services for women, for migrant workers, for seniors, and services supporting families. These programs influence migrant families' social support in various ways at different levels.

Table 2: An overview of social services in $T$ village

\begin{tabular}{|c|c|c|c|c|}
\hline $\begin{array}{c}\text { Types } \\
\text { of } \\
\text { service }\end{array}$ & $\begin{array}{c}\text { Involved } \\
\text { program/projec } \\
\text { t/activities }\end{array}$ & $\begin{array}{c}\text { Funders \& service } \\
\text { providers }\end{array}$ & Description of the programs & Delivery \\
\hline \multirow[t]{3}{*}{$\begin{array}{l}\text { Youth } \\
\text { services }\end{array}$} & Tutorial program & $\begin{array}{l}\text { Shanghai Civil Affair } \\
\text { Bureau (SHCAB) / } \\
\text { SWers / volunteers }\end{array}$ & $\begin{array}{l}\text { After-school tutorial on math, arts, and } \\
\text { English provided by college students for } \\
\text { migrant children from grade one to five, } \\
\quad 3,000 \text { sessions completed }\end{array}$ & \multirow{3}{*}{$\begin{array}{c}\text { Project- } \\
\text { based } \\
\text { programs, } \\
\text { renewed } \\
\text { every one or } \\
\text { two years, } \\
\text { starting } \\
\text { from } 2009\end{array}$} \\
\hline & Summer camp & $\begin{array}{l}\text { SHCAB / SWers / } \\
\text { volunteers }\end{array}$ & $\begin{array}{c}\text { Supervision and recreational activities } \\
\text { during summer vacation }\end{array}$ & \\
\hline & $\begin{array}{l}\text { "Growing up } \\
\text { companion" plan }\end{array}$ & $\begin{array}{l}\text { SHCAB / SWers / } \\
\text { schools }\end{array}$ & $\begin{array}{l}\text { One-to-one adult helping the child with } \\
\text { educaiotnal advice and development } \\
\text { support }\end{array}$ & \\
\hline \multirow[t]{2}{*}{$\begin{array}{l}\text { Parental } \\
\text { support }\end{array}$} & $\begin{array}{l}\text { Parent-child } \\
\text { sports meeting }\end{array}$ & SWers / volunteers & $\begin{array}{l}\text { Entertaining sports for participation of } \\
\text { parents and children to facilitate parent- } \\
\text { child interactions }\end{array}$ & \multirow{2}{*}{$\begin{array}{c}\text { Additional } \\
\text { activities } \\
\text { from youth } \\
\text { services, } \\
\text { conducted } \\
\text { in } 2010 \& \\
2011\end{array}$} \\
\hline & $\begin{array}{l}\text { Good mothers } \\
\text { salon in T village }\end{array}$ & Researchers / SWers & $\begin{array}{l}\text { Mothers sharing parenting experience and } \\
\text { family stories through photo voice projects }\end{array}$ & \\
\hline $\begin{array}{l}\text { Services } \\
\text { for } \\
\text { seniors }\end{array}$ & Tai Chi group & $\begin{array}{l}\text { SWers / the } \\
\text { neighbourhood } \\
\text { committee }\end{array}$ & $\begin{array}{l}\text { Exercises and exchanges of health } \\
\text { promotion activities }\end{array}$ & $\begin{array}{l}\text { Project- } \\
\text { based } \\
\text { program } \\
\text { starting } \\
\text { from } 2010\end{array}$ \\
\hline \multirow[t]{2}{*}{$\begin{array}{l}\text { Services } \\
\text { for } \\
\text { women }\end{array}$} & $\begin{array}{l}\text { Room of "Care } \\
\text { for Women in T } \\
\text { village" }\end{array}$ & $\begin{array}{l}\text { Township office for } \\
\text { migrant / SWers / the } \\
\text { neighbourhood } \\
\text { committee }\end{array}$ & $\begin{array}{l}\text { Maternal \& reproductive health services, } \\
\text { profile pregnant information, and advocate } \\
\text { state's family planning policy }\end{array}$ & \multirow{2}{*}{$\begin{array}{l}\text { Regular } \\
\text { services } \\
\text { starting } \\
\text { from } 2009\end{array}$} \\
\hline & $\begin{array}{l}\text { Self-support } \\
\text { groups for } \\
\text { women }\end{array}$ & SWers & Group work for women & \\
\hline $\begin{array}{l}\text { Services } \\
\text { for } \\
\text { migrant }\end{array}$ & $\begin{array}{l}\text { Lecture on social } \\
\text { insurance } \\
\text { programs for }\end{array}$ & $\begin{array}{l}\text { Township office for } \\
\text { migrants/ social } \\
\text { workers }\end{array}$ & $\begin{array}{l}\text { Employment counselling, providing } \\
\text { updated policy and insurance programs } \\
\text { through lectures and billboards }\end{array}$ & $\begin{array}{l}\text { Project- } \\
\text { based } \\
\text { program }\end{array}$ \\
\hline
\end{tabular}


Wen, Ya, \& Hanley, Jill. (2016). Enhancing Social Support for Migrant Families: A Case Study of Community Services in a Shanghai Urban Village and Implications for Intervention. Asian Social Work and Policy Review, 10(1), 76-89.

\begin{tabular}{|c|c|c|c|c|}
\hline \multirow[t]{2}{*}{ workers } & migrants & & & \multirow{2}{*}{$\begin{array}{c}\text { renew every } \\
\text { year, } \\
\text { starting } \\
\text { from } 2010\end{array}$} \\
\hline & $\begin{array}{l}\text { Group work on } \\
\text { "meeting fellow } \\
\text { villagers" }\end{array}$ & SWers & Group work for migrant workers & \\
\hline $\begin{array}{l}\text { Family } \\
\text { support }\end{array}$ & $\begin{array}{l}\text { Family } \\
\text { empowerment } \\
\text { plan }\end{array}$ & $\begin{array}{l}\text { Hong Kong charitable } \\
\text { organization / } \\
\text { University's social } \\
\text { work department / } \\
\text { SWers }\end{array}$ & $\begin{array}{l}\text { Household visits and case work for } \\
\text { families }\end{array}$ & $\begin{array}{l}\text { Project- } \\
\text { based } \\
\text { program } \\
\text { starting } \\
\text { from } 2012\end{array}$ \\
\hline \multirow{2}{*}{$\begin{array}{l}\text { Commu } \\
\text { nity } \\
\text { activitie } \\
\text { s }\end{array}$} & Outdoor films & SWers & $\begin{array}{l}\text { Played } 24 \text { films for more than } 1,110 \\
\text { migrants }\end{array}$ & \multirow{2}{*}{$\begin{array}{l}\text { Annual } \\
\text { activities } \\
\text { starting } \\
\text { from } 2010\end{array}$} \\
\hline & $\begin{array}{l}\text { Community } \\
\text { library }\end{array}$ & $\begin{array}{l}\text { SHCAB / SWers / the } \\
\text { neighbourhood } \\
\text { committee }\end{array}$ & $\begin{array}{l}\text { Collecting more than } 2,000 \text { books and } \\
\text { magazines and making a reading room } \\
\text { available for migrants }\end{array}$ & \\
\hline
\end{tabular}

As we can see, the first level of the services is centred on families' needs. The services for youth are mainly conducted by social workers and focus on migrant children's well-being and their need to adapt to the locale and to the schools. The tutorial program exists to help families that lack the capacity and/or resources to supervise their children's studies and provides academic assistance and other resources to help children with their schoolwork and adapt to the locale. The information seminars are given by social workers in collaboration with the township level of administrative for migrant populations and target migrants' need for employment and for updated welfare information. According to a social worker, these programs helped social workers to 'break the ice' and established relations with migrants for meeting their primary and pressing needs, and they also allowed further service provision by involving other members of the families.

The second level is to promote migrants' interpersonal relations. According to a social worker, as a village on the move, neighbourly relationships in $\mathrm{T}$ village were far less important than those with laoxiang ( rural network of people sharing close geographic ties). Neighbours were just "nodding acquaintances", without really knowing each other, making T village "an island of strangers". To 
address the situation, social workers developed a few programs to enhance interpersonal relations among migrants, such as the "women's self-help groups" and "meeting your fellow villagers".

$\mathrm{Hu}$ (pseudonym name) was a participant in the women's self-help group. According to social workers, there were many women, like $\mathrm{Hu}$, who wanted to find a job, but the responsibilities of taking care of young children kept her at home and isolated from the world outside family. In this program, migrant women got to know and support each other. They helped with child pick-up and provided emotional support to each other. Hu and another member of this support group also started a small business selling cross-stitching and other handicraft work online. The services emphasizing support exchange helped migrants increase interactions and establish diverse networks in the village, facilitating their access to more social support.

The third level is to mobilize external resources to build the community assets of T village. Social workers believed that it was important to help migrants obtain external resources outside of the village, given that $\mathrm{T}$ village is relatively isolated and lacks basic community resources and infrastructure common to other urban communities. One such an example was the community library started in 2011 as a community tendering and bidding project funded by the local Civil Affairs Department. In this project, social workers, with the assistance of the neighbourhood committee, established a community library in $\mathrm{T}$ village by drawing on external resources, such as public libraries and university organizations. Now, the community library holds more than 2,000 books and a dozen newspapers and magazines, which are all free for migrant residents to read. Although the library is just a small room with a limited number of books, it is easily accessible by migrants for their recreational activities, eventually becoming a public asset of the village. Certain youth services were offered in the library; migrants went there to chat and socialize. Residents voluntarily maintained the operation of the library, 
which has strengthened community ties and networks.

A class of the summer camp

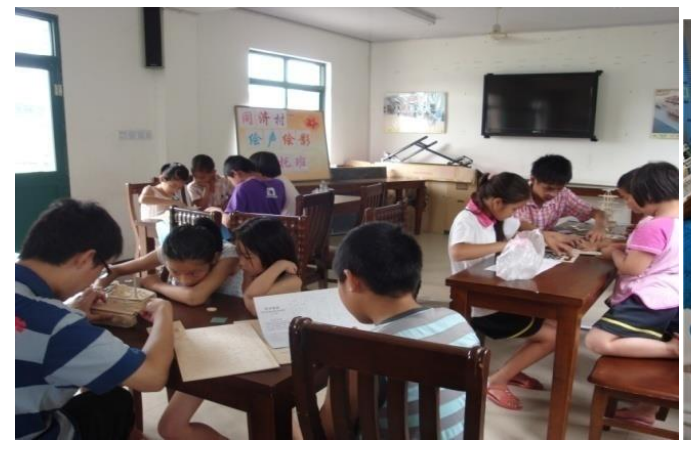

In the community library

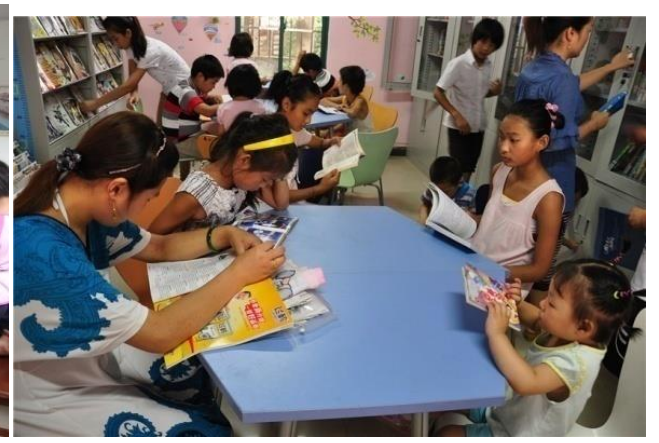

Besides the library project, social workers also launched a few programs aim to link residents to resources outside of the village: a local legal aid office, nearby schools, volunteer organizations, and enterprises. Through these programs, social workers brought together resources and strengths from different sources to change the infrastructure of $\mathrm{T}$ village and improve community assets. According to one service provider, "our capacity is limited, but we can work as the bridge of urban public services and the migrants in the village, helping them access those services" (B6).

The final level of social support involves enhancing community support and empowerment. Many migrant residents did not see $\mathrm{T}$ village as their permanent residence, but rather as a temporary shelter. They lacked of a sense of community and demonstrated little interest in civic engagement for the overall good of the community, a situation that affected the overall community support available for the residents. As one service provider said, "the residents in the village are like a bunch of sand. They need to be bonded together as a community, and social workers should serve as the glue" (D10). Under the circumstances, a volunteer team for community environment protection was established. It was initiated by the neighbourhood committee, as environment protection was part of their daily administrative duties. With the assistance of social workers, the team expanded to about 50 volunteers, including a mix of migrants and local residents, who helped community sanitary workers to keep the 
village clean and advocated on environmental protection. The work of the volunteer team effectively reduced the undesired environmental behaviours of residents. The establishment of the volunteer team was the very first step toward building self-organization in T village, which faced many challenges ahead. According to one social worker, migrants tended to feel they were making a sacrifice when participating in community volunteer activities because they were often engaged in working in long hours to make a living.

\section{Social work practices to enhance migrant families' social support---An intervention framework}

We have argued elsewhere that rural-to-urban migrant families rely on their informal social networks for social support, networks that are reciprocal, trustful, and do not involve any feeling of losing face (Wen \& Hanley, 2015). However, given the complex needs of migrant families integrating into the cities, their limited kinship or rural guanxi networks are often incapable of providing them important resources and support. Our findings suggest that, although migrant families rely on informal social support, their social support can be enhanced through community services. There is great potential for social work interventions on social support, professional helping strategies that create or increase social support for targeted population, providing either direct support or enhancing existing informal networks ().

In our case study, four levels of interventions can be identified: (1) by meeting migrants' immediate needs; (2) by strengthening their existing links and support exchange in the village; (3) by incorporating new sources of support and mobilizing external resources to build community assets; or (4) by enhancing community support and empowerment. Based on the findings, we suggest a framework that differentiates between levels of social support in order to emphasize the integration of formal and informal support sources. Table 3 provides an illustration of this framework. 
Wen, Ya, \& Hanley, Jill. (2016). Enhancing Social Support for Migrant Families: A Case Study of Community Services in a Shanghai Urban Village and Implications for Intervention. Asian Social Work and Policy Review, 10(1), 76-89.

\begin{tabular}{|c|l|l|}
\hline \multicolumn{2}{|c|}{ Table 3: Differentiation of the levels of social support intervention for migrants } \\
\hline Level of intervention & \multicolumn{2}{|c|}{ Changes in social support dimension } \\
\hline $\begin{array}{c}\text { Direct support (given } \\
\text { directly to recipients) }\end{array}$ & No changes in the social network & $\begin{array}{l}\text { Information and advice } \\
\text { Instrumental support }\end{array}$ \\
\hline $\begin{array}{c}\text { Social support } \\
\text { exchange }\end{array}$ & $\begin{array}{c}\text { Increased frequency of contact } \\
\text { among migrants } \\
\text { Increased reciprocity }\end{array}$ & $\begin{array}{l}\text { Emotional support } \\
\text { Information and advice } \\
\text { Instrumental support and material aid }\end{array}$ \\
\hline $\begin{array}{c}\text { Social network } \\
\text { intervention }\end{array}$ & $\begin{array}{l}\text { Incorporation of multiple new } \\
\text { sources of support } \\
\text { Changes in network composition } \\
\text { Less density and dispersion }\end{array}$ & $\begin{array}{l}\text { Information and advice } \\
\text { Instrumental support } \\
\text { Increased potential support exchanges }\end{array}$ \\
\hline $\begin{array}{c}\text { Community support } \\
\text { and empowerment }\end{array}$ & $\begin{array}{l}\text { Strengthening of social network } \\
\text { ties } \\
\text { Increased awareness and capacity } \\
\text { to generate and use support } \\
\text { Change of power structure }\end{array}$ & $\begin{array}{l}\text { Increased level of community collectives } \\
\text { and social capital }\end{array}$ \\
\hline
\end{tabular}

Interventions that focus on migrants' immediate needs and that address pressing problems in their lives — such as children's school enrolment and legal aid for labour rights—fall into the category of direct support intervention. This includes providing information, advice, as well as instrumental support, but does not involve changes to social network structure. For example, the youth services in T village provide academic assistance and companionship support to make up for migrant families' inability to provide these types of social support for their children. By addressing their immediate needs, direct support intervention is attractive to migrants and therefore useful for breaking the ice and building relationships at the beginning of service provision. However, an obvious limitation of this level of intervention is it falls short to address migrants' needs for long-term adaption and facilitate their own capabilities to improve their lives.

Social support exchange intervention includes actions to identify and mobilize existing informal support sources in migrant communities, in order to improve social support exchange. The social supports brought forth by this level of intervention may include emotional support, information and 
advice, material assistance, and instrumental support. An increased frequency of contact and reciprocity are expected with this level of social support intervention. The promotion of existing sources of support may improve resident interactions and neighbourhood relationships, more broadly; it is thus particularly appropriate for urban villages where neighbour relationships are weak (Neufeld et al., 2002). Like the "women's mutual support group" in T village, small, voluntary groups of individuals with common needs, interests, and objectives could be formed whose main purpose would be to provide reciprocal help and solve shared problems. However, social work professionals should be cautious that the structural basis of most social problems should be made explicit to the group involved in the intervention. While mutual support initiatives may help alleviate difficult conditions, structural changes are likely required to change the fundamental conditions that contribute to the difficulties faced by rural-to-urban migrants.

Social network intervention involves changes to the structure and function of migrants' informal support systems by incorporating new interpersonal relationships outside of the community and by mobilizing diverse types of resources. This is particularly appropriate for migrants living in geographically isolated and socially segregated urban villages. Through this type of intervention, external resources can be incorporated to provide instrumental assistance, emotional support, opportunities for social participation, and information about the city. As in the community library project in T village, in this type of intervention, social workers should not only act as 'bridges' linking the urban village to external resources from larger urban society, but they should also act as facilitators of the process of mobilizing external resources to build community assets. In this type of intervention, migrants are also expected to be actively involved in the process and to contribute to community asset building. 
Social support exchange and social network interventions can be viewed as the basis for community support and empowerment, which emphasizes migrants' participation in the identification of collective needs, the development of strategies to address those needs, and the implementation of actions to that end. At this level, the main aim of intervention is not only the improvement of social support, but also the promotion of community empowerment and social change (Plaze et al., 2006). Putnam (1993) described social capital as a community-level resource and defined it as a feature of social organizations, whereby networks, norms and social trust facilitate cooperation for mutual benefit. Low levels of social capital may leave neighbours without any incentive to cooperate due to a lack of a generalized sense of trust or common interest. Moreover, urban villages often face structural disadvantages, such as residential instability, deprivation of important community resources, and high levels of social disorganization (Ke \& Li, 2001). These conditions can negatively affect family practices and children's development (Beyers, et al, 2003). Therefore, to address this, a greater accumulation of community social capital and an improvement of a sense of collective interest is needed. Community-level interventions that emphasize migrants' participation and trust-building foster collective efficacy and strengthen community cohesion, which directly and indirectly benefit the healthy development of migrant children and adolescents who live in urban villages with their families (Whittaker et al., 2009).

\section{Implications and conclusion}

Social support is essential for migrants' psychological well-being in managing the ongoing challenges that arise from the migration-adaptation process. However, limited social networks and institutional barriers impede rural-to-urban migrants' accessing and mobilizing diverse social support to meet their needs of integrating into the city. Therefore, interventions on social support are necessary, 
with an emphasis on integrating formal and informal support, that is, an increase in formal supports permits the enhancement of informal resources, social networks, and the ability of migrants to effectively solve problems and change their lives.

A limitation of our study is that it is based on one case study in a Shanghai urban village. However, the study provides insight into how social work practices may exert influence on service provision for migrant population and enhance social support for migrant families in urban villages. Social work is still considered a newly-developed discipline in China. Providing social services for migrants in urban villages offers an important opportunity for developing a professional social work identity that is distinct from other community workers. As a profession upholding social justice and promoting social change, social workers should engage in facilitating migrants' self-organization and empowerment for the healthy development of urban village.

Moreover, with more migrant households on the move and with urban villages acting as gateways for migrants to integrate into larger cities, the need for more community services to improve migrants' welfare is growing. The development of community services for rural-to-urban migrants is still in its preliminary stages, but it is impelled by migration-related policy shifts. Social workers will be able to make even greater contributions as their experience and influence grows. As one social worker said,

The ultimate goal of our offering community services is essentially to help migrants improve their life in T village. And the key is to help them help themselves. Only when migrants can actively seek support for themselves and are able to mobilize their resources and networks to meet their various needs, will they find the way to integrate into the city. (A1) 


\section{References}

Beyers, J. M., Bates, J. E., Pettit, G. S., \& Dodge, K. A. (2003). Neighbourhood structure, parenting processes, and the development of youths' externalizing behaviours: A multilevel analysis. American Journal of Community Psychology, 31(1/2): 35-53.

Cai, F. \& Wang, D. (2007). Impacts of internal migration on economic growth and urban development in China. Institute of Population and Labour Economics, CASS.Retrievedfromhttp://iple.cass.cn/file/Impacts_of_Internal_Migration_on_Economic_Gro wth\%20 and Urban Development.pdfon February 22,2011.(in Chinese)

Gransow, B. (2011). Slum formation or urban innovation? Migrant communities and social change in Chinese megacities. In Bade, K. J., Lorentz, B., Pries, L. (eds.): Migration and IntegrationReflection on our Common Future. Leipzig.

Greeff, A. P. \& Holtzkamp, J. (2007). The prevalence of resilience in migrant families. Family Community Health, 30(3): 189-200.

Guan, X. P. (2010). The role of social work in social services for migrant workers: Needs, content, and main areas. Studies \& Practices, 4: 91-99. (in Chinese)

Harker, K. (2001).Immigrant generation, assimilation, and adolescent psychological well-being. Social Forces, 79: 969-1004.

Hebert, Y., Sun, Y. S., \& Kowch, E. (2004).Focusing on children and youth: The role of social capital in educational outcomes in the context of immigration and diversity. Journal of International Migration and Integration, 5:229-249.

Jencks, C. \& Mayer, S. E. (1990). The social consequences of growing up in a poor neighbourhood. In L. E. Lynn \& M. F. McGeary (Eds.), Inner-city Poverty in the United States (pp111-186). Washington, DC: National Academy Press.

Ke. L. J. \& Li, H. L. (2001). Villages in Cities: The Floating Population in Chinese Metropolitans, Beijing: Central Compilation and Translation Press. (in Chinese)

Lin, N. (1986). Conceptualization social support. In N. Lin, A. Dean, \& Ensel (Eds.), Social support, life events, and depression (pp17-30). New York: Academic Press.

Lopez, E. J. \& Salas, L. (2006).Assessing social support in Mexican American high school students: a validity study. Journal of Hispanic Higher Education, 5, 97-106.

Ministry of Civil Affairs (1995).National Criteria of Community Services. Beijing, Ministry of Civil Affairs of People Republic of China. 
Wen, Ya, \& Hanley, Jill. (2016). Enhancing Social Support for Migrant Families: A Case Study of Community Services in a Shanghai Urban Village and Implications for Intervention. Asian Social Work and Policy Review, 10(1), 76-89.

National Health and Family Planning Commission (2014). 2014 Report on China's Migrant Population Development. Beijing: China Population Publishing House.

Putnam, R. D. (1993). The prosperous community: social capital and public life. The American Prospect, 4: 35-42.

Ryan, L., Sales, R, Tilki, M., \& Siara, B. (2008). Social networks, social support and social capital: The experiences of recent polish migrants in London. Sociology, 42:672-689.

Simich, L., Beiser, M., Stewart, M., \& Mwakarimba, E. (2005).Providing social support for immigrants and refugees in Canada: Challenges and directions. Journal of Immigrant Health, 7(4): 259-269.

Song, Y., Zenou, Y. \& Ding, C. R. (2008). Let's not throw the baby out with the bath water: The role of urban villages in housing rural migrants in China. Urban Studies, 45(2): 313-330.

State Council, (2006).Opinion on Resolving the Problems Faced by Migrant Workers. http://www.gov.cn/jrzg/2006-03/27/content 237644.htm

Sun, L. (2013).Current Situation and Human Settlements Remediation of Chinese Urban Village. Beijing: China Architecture \& Building Press. (in Chinese)

Tracy, E. M. \& Whittaker, J. K. (1987). The evidence base for social support interventions in child and family practice: Emerging issues for research and practice. Children and Youth Service Review, 9(4): 249-270.

Wen, Y. \& Hanley, J. (2015).Rural-to-urban migration, family resilience, and policy framework for social support in China. Journal of Asian Social Work \& Policy Review, 9(1):18-28.

Whittaker, J. K., Tracy, E. M., Overstreet, E., Mooradian, J., \& Kapp, S. (2009). Intervention design for practice-enhancing social supports for high risk youth and families. In E. J. Thomas \& J., Rothman (eds.) Intervention Research: Design and Development for Human Service (pp195208). New York: Routledge.

Xu, Q. W. \& Chow, J. C. (2006).Urban community in China: Service, participation and development. International Journal of Social Welfare, 15: 199-208.

Xu, Q. W., Guan, X. P. \& Yao, F. F. (2011). Welfare program participation among rural-to-urban migrant workers in China. International Social Welfare. 20: 10-21.

Yan. M. C. \& Gao, J. G. (2007). Social engineering of community building: Examination of policy process and characteristics of community construction in China. Community Development Journal. 42(2): 222-236. (in Chinese) 